\title{
On the syntax of 'why'-like 'how' in Korean \\ Okgi Kim*
}

\begin{abstract}
The wh-phrase ettehkey 'how' in Korean is forced to be interpreted as a reason $w h$-adverbial corresponding to way 'why' when it occurs with a causative -key toy-construction with past tense. In this paper, I try to answer a simple but fundamental question of whether or not reason ettehkey is base-generated in the same position as the 'high' wh-adjunct way (Ko 2005, 2006). I argue that reason ettehkey in an interrogative clause is externally merged in its checking position, Spec- $\mathrm{C}_{\text {Int }} \mathrm{P}$, just like way (Ko 2006), whereas manner/instrumental ettehkey originates below NegP.
\end{abstract}

Keywords. reason ettehkey; manner/instrumental ettehkey; Intervention Effect; Anti-Superiority Effect; Negative Island Effect

1. Introduction. In Korean, the wh-word ettehkey, which corresponds to English how, is standardly used as a question whose answer could be manner or instrumental, as illustrated in (1).

(1) A: John-un ettehkey kkochpyeng-ul kkayss-ni?

John-TOP how vase-ACC broke-QUE

'How did John break the vase?'

B: amwu cwuce epsi [manner]

any hesitation without

'Without any hesitation'

$\mathrm{B}^{\prime}$ : mangchi-lo [instrumental]

hammer-with

'With a hammer'

However, the usage of ettehkey is not restricted to such cases. The $w h$-item can be also used non-standardly in that it is forced to be interpreted as a reason wh-adverbial when it occurs with a causative -key toy-construction with past tense. ${ }^{1}$ This type of ettehkey (henceforth, reason ettehkey) is exemplified in (2A) (here and throughout the paper, the ${ }^{\mathrm{w}}$ superscript is used in glossing reason ettehkey and distinguishing it from its standard counterpart (i.e., manner/instrumental ettehkey)). ${ }^{2}$

(2) A: John-un $\left\{\right.$ ettehkey $^{\mathbf{w}} /$ way $\}$ kkochpyeng-ul kkay-key toyess-ni?

John-TOP how/why vase-ACC break-CONN became-QUE

'Why did John break the vase?'

B: silswulo patak-ey ttelettulyess-e.

by.mistake floor-LOC dropped-DECL

'(He) dropped (it) on the floor by mistake.'

B': \#amwu cwuce epsi

any hesitation without

'Without any hesitation

\footnotetext{
* Author: Okgi Kim, University of Wisconsin-Milwaukee (okgikim@uwm.edu).

${ }^{1}$ See Yeo (2019) for discussion of causative -key toy-constructions.

${ }^{2}$ See Tsai (2008) for discussion of Chinese how-why alternations.
} 


\section{$\mathrm{B}^{\prime \prime}$ : \#mangchi-lo \\ hammer-with \\ 'With a hammer}

The construal of ettehkey as a reason $w h$-adverbial is verified by the fact that it can be replaced by the regular reason wh-adjunct way why, without affecting the intended meaning of a sentence, as indicated in $(2 \mathrm{~A})$.

The 'why'-like behavior of ettehkey introduced above raises many important theoretical questions in terms of syntax, one of which is whether or not reason ettehkey originates in the same position as the 'high' wh-adjunct way (Ko 2005, 2006). ${ }^{3}$ This simple but fundamental question - to my knowledge-has not previously been answered in the literature. Therefore, this paper aims to address the research gap. In this paper, building on Ko's (2006) analysis of wh-licensing in Korean, I argue that, like way, reason ettehkey in an interrogative clause is base-generated in its checking position, Spec- $\mathrm{C}_{\mathrm{Int}} \mathrm{P}$, while manner/instrumental ettehkey originates below NegP and undergoes covert movement to $S p e c-C_{F o c} P$, configured higher than $C_{\text {Int }} P$ (cf. Rizzi 1999, 2001).

The paper is organized as follows. In the following section, I present similarities between reason ettehkey and way with regard to the Intervention Effect and the Anti-Superiority Effect. In Section 3, I present Ko's (2006) analysis of way. Section 4 discusses where the two variants of ettehkey are base-generated and how they are licensed, based on Ko's analysis. In Section 5, I conclude.

2. Similarities with way: Intervention Effect and Anti-Superiority Effect. Reason ettehkey behaves like the regular reason wh-adjunct way in terms of the Intervention Effect: unlike other wh-phrases, including manner/instrumental ettehkey, both reason ettehkey and way can be preceded by a Scope Bearing Element (SBE) (a.k.a. an intervener) like amwuto 'anyone' that gives rise to the Intervention Effect when it c-commands a wh-phrase (see, among others, Beck \& Kim 1997; Ko 2005; Beck 2006; Kotek 2014 for detailed discussions of the Intervention Effect). Consider the following examples:

a. *amwuto Mary-eytayhay ettehkey malha-ci anh-ass-ni? anyone Mary-about how talk-CONN not-PST-QUE 'How was no one talking about Mary?'

b. John-i ettehkey Mary-eytayhay amwu-eykey-to malha-ci anh-ass-ni? John-NOM how Mary-about anyone-to talk-CONN not-PST-QUE 'How was John talking to no one about Mary?' (adapted from Choi 2007)

a. amwuto $\left\{\right.$ ettehkey $\left.^{\mathbf{w}} / \mathbf{w a y}\right\}$ nonmwun-ul ilk-ci anh-key toyess-ni? anyone how/why paper-ACC read-CONN not-CONN became-QUE 'Why didn't no one read papers?'

b. $\quad$ ettehkey $\left.{ }^{\mathrm{w}} / \mathbf{w a y}\right\}$ amwuto nonmwun-ul ilk-ci anh-key toyess-ni? how/why anyone paper-ACC read-CONN not-CONN became-QUE 'Why didn't no one read papers?'

Example (3) shows that manner/instrumental ettehkey cannot follow but must precede the SBE. On the other hand, example (4) illustrates that both reason ettehkey and way can follow or pre-

\footnotetext{
${ }^{3}$ I leave to future research the crucial issue of how 'why'-like meaning is derived from non- 'why'-like $w h$-items like
} ettehkey. 
cede the SBE.

Reason ettehkey also patterns like way, and unlike other wh-phrases, with respect to the Anti-Superiority Effect in that it is unable to precede the other wh-phrase in a multiple whquestion (see, among others, Watanabe 1992 and Saito 1994 for detailed discussions of the Anti-Superiority Effect):

(5) a. John-un ettehkey mwues-ul kkayss-ni?

John-TOP how what-ACC broke-QUE

'What did John break how?'

b. John-un mwues-ul ettehkey kkayss-ni?

John-TOP what-ACC how broke-QUE

'What did John break how?'
a. *John-un $\left\{\right.$ ettehkey $\left.^{\mathbf{w}} / \mathbf{w a y}\right\}$ mwues-ul kkay-key toyess-ni?
John-TOP how/why what-ACC break-CONN became-QUE
'What did John break why?'
b. John-un mwues-ul \{ettehkey $\left.{ }^{\mathbf{w}} / \mathbf{w a y}\right\}$ kkay-key toyess-ni?
John-TOP what-ACC how/why break-CONN became-QUE
'What did John break why?'

As observed in (5), manner/instrumental ettehkey can precede or follow the wh-argument mwues$u l$. However, as shown in (6), both reason ettehkey and way cannot precede but must follow the $w h$-argument in the multiple wh-question.

3. Ko (2006): the external merge of way in Spec- $C_{\text {Int }} P$. To explain the peculiar behavior of way with respect to the Anti-Superiority Effect, i.e., its inability to precede the other wh-phrase in a multiple wh-question (see (6)), Ko (2006), following Rizzi's (1999) split-CP hypothesis, assumes that way in an interrogative clause is base-generated in its checking position, Spec$\mathrm{C}_{\text {Int }} \mathrm{P}$, as illustrated in (7a), while other wh-operators covertly move from their base position to Spec- $\mathrm{C}_{\mathrm{Foc}} \mathrm{P}$, configured higher than $\mathrm{C}_{\text {Int }} \mathrm{P}$, for feature checking, as illustrated in (7b). ${ }^{4}$
a. $\quad\left[\begin{array}{lllll}\mathrm{CP} & \mathrm{C}_{\mathrm{Foc}[+\mathrm{Q}]} & \ldots & \text { way } & \mathrm{C}_{\mathrm{Int}[+\mathrm{Q}]}\left[\begin{array}{lll}\mathrm{II} & \ldots & \end{array}\right]\end{array}\right]$

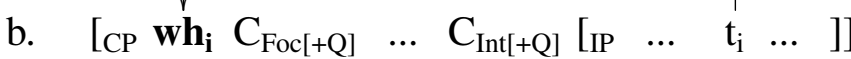

Ko further assumes that unlike other $w h$-items, way is an SBE that induces the Intervention Effect which she takes as a constraint on $w h$-movement at LF, where a wh-phrase cannot be attracted to its checking/scope position across an SBE, as illustrated in (8) (see also Ko 2005; cf. Beck \& Kim 1997). ${ }^{5}$

${ }^{4} \mathrm{C}_{\text {Int }} \mathrm{P}$ and $\mathrm{C}_{\mathrm{Foc}} \mathrm{P}$ correspond to IntP and FocP, respectively, in Rizzi's split-CP system for Romance languages.

${ }^{5}$ Ko takes way as an SBE given that it induces focus association, where the answer to a way-question differs depending on the association between way and a focus-marked phrase with emphatic stress (see also Bromberger 1992):

(i) a. A: way Adam-i sakwa-lul mek-ess-ni?

why Adam-NOM apple-ACC eat-PST-QUE

'Why did Adam eat the apple?'

B: hanunim-i kukes-ul uytohasiessu-nikka

God-NOM that-ACC intend-because

'because God intended it (to happen)'

b. A: way ADAM-i sakwa-lul mek-ess-ni? 


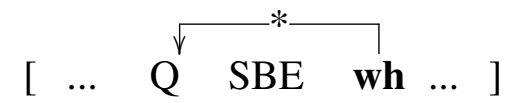

Let us now examine how Ko's analysis accounts for the Anti-Superiority Effect. Under her analysis, the Anti-Superiority Effect arises because way as an SBE gives rise to the Intervention Effect by blocking LF movement of the other wh-phrase that it c-commands. ${ }^{6}$ For example, (6a) is ruled out because LF movement of the wh-argument mwues-ul to $\mathrm{Spec}-\mathrm{C}_{\mathrm{Foc}} \mathrm{P}$ is interfered with by the SBE way sitting in Spec- $\mathrm{C}_{\text {Int }} \mathrm{P}$, configured lower than $\mathrm{C}_{\mathrm{Foc}} \mathrm{P}$, as illustrated in (9).

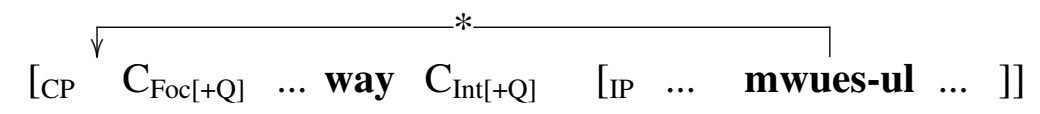

Ko's analysis also explains the asymmetry between way and other wh-phrases in terms of the Intervention Effect, where only the former is not subject to the Intervention Effect when c-commanded by an SBE in an interrogative clause (see the contrast between (3a) and (4a)). According to the Intervention Effect constraint, the ungrammaticality of (3a), where manner/instrumental ettehkey is preceded by the SBE amwuto, is because LF movement of the whphrase to Spec- $\mathrm{C}_{\mathrm{Foc}} \mathrm{P}$ is blocked by the c-commanding SBE, resulting in a derivational crash, as illustrated in (10).

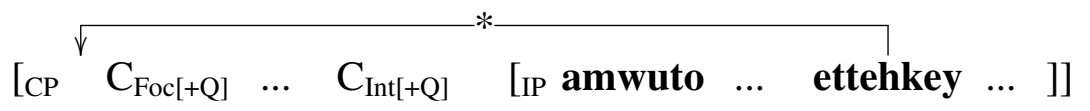

On the other hand, the well-formedness of $(3 b)$ is because manner/instrumental ettehkey, which is not in the c-commanding domain of the SBE, can freely move to its checking position at LF, as illustrated in (11).

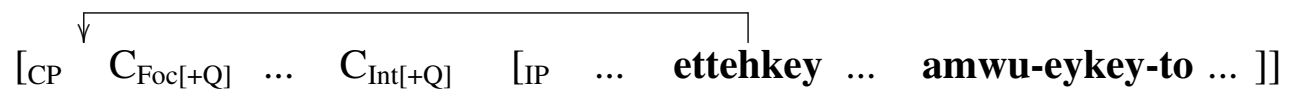

Meantime, as we have seen in (4), unlike manner/instrumental ettehkey, the reason wh-adverb way can follow an SBE that induces the Intervention Effect. This is because way is licensed in its base position (i.e., Spec- $\mathrm{C}_{\mathrm{Int}} \mathrm{P}$ ) and, therefore, does not move at LF. For example, (4a) is assumed to involve the LF structure given in (12), where the SBE has undergone overt scrambling over way licensed in Spec- $\mathrm{C}_{\mathrm{Int}} \mathrm{P}$.

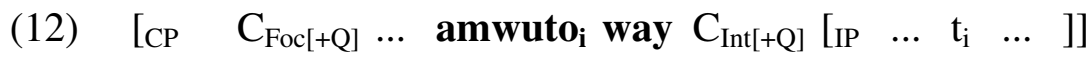

\footnotetext{
B: Ivu-ka Adam-eykey kwonhayssu-nikka Eve-NOM Adam-DAT recommended-because 'because he was the one that Eve recommended (to eat the apple)'

c. A: way Adam-i SAKWA-lul mek-ess-ni?

B: kukes-i cwupyeney iss-ten yulihan umsik iessu-nikka that-NOM around be-MOD only food be-because 'because it (the apple) was the only food around'

d. A: way Adam-i sakwa-lul MEK-ess-ni?

B: kukes-ulo mwues-ul halci mollassu-nikka that-with what-ACC to.do be.ignorant.of-because 'because he couldnt think of anything else to do with it'

${ }^{6}$ She thus takes the Anti-Superiority Effect as a variant of the Intervention Effect.
} 
The well-formed sentence in (4b) is simply explained since way is not in the intervention configuration, that is, it is not c-commanded by the SBE, as illustrated in (13).

\section{(13) $\left[\mathrm{CP} \quad \mathrm{C}_{\mathrm{Foc}[+\mathrm{Q}]} \ldots \quad\right.$ way $\mathrm{C}_{\mathrm{Int}[+\mathrm{Q}]}[\mathrm{IP}$ amwuto $\ldots]$.}

\section{Base positions of the two variants of ettehkey.}

4.1. BASE-GEneration OF REASOn ettehkey In SPEC-C $\mathrm{C}_{\text {InT }} \mathrm{P}$. As we have observed in Section 2, reason ettehkey behaves exactly like the regular wh-adjunct way in regard to the Intervention Effect and the Anti-Superiority Effect. If Ko's analysis discussed in the previous section is on the right track, it may be reasonable to assume that reason ettehkey in an interrogative clause is base-generated in the same checking/scope position as way, namely $\mathrm{Spec}-\mathrm{C}_{\mathrm{Int}} \mathrm{P}$.

The base-generation of reason ettehkey in Spec- $\mathrm{C}_{\text {Int }} \mathrm{P}$ is supported by the fact that, unlike manner/instrumental ettehkey, it cannot cooccur with way, as in (14); the two wh-expressions compete for the same licensing position $\left(\right.$ Spec- $\left.\mathrm{C}_{\text {Int }} \mathrm{P}\right)$.

$$
\begin{aligned}
& \text { a. *John-un ettehkey }{ }^{\text {w }} \text { way kkochpyeng-ul kkay-key toyess-ni? } \\
& \text { John-TOP how why vase-ACC break-CONN became-QUE } \\
& \text { 'Why did John break the vase?' } \\
& \text { b. *John-un way ettehkey kkochpyeng-ul kkay-key toyess-ni? } \\
& \text { John-TOP why how vase-ACC break-CONN became-QUE } \\
& \text { 'Why did John break the vase?' }
\end{aligned}
$$
a. ?John-un ettehkey way kkochpyeng-ul kkayss-ni?
John-TOP how why vase-ACC broke-QUE
'Why did John break the vase how?'
b. *John-un way ettehkey kkochpyeng-ul kkayss-ni? John-TOP why how vase-ACC broke-QUE 'Why did John break the vase how?'

Note that the ill-formedness of (15b), where manner/instrumental ettehkey is preceded by way, is due to the Intervention Effect induced by the SBE way, as discussed before.

Another source of support for the external merge of reason ettehkey in $\mathrm{Spec}-\mathrm{C}_{\text {Int }} \mathrm{P}$ arises from the fact that it takes obligatory wide scope over negation, just like way (Ko 2005):

John-un $\left\{\right.$ ettehkey $\left.^{\text {w/way }}\right\}$ mikwuk-ey ka-ci anh-key toyess-ni?

John-TOP how/why America-to go-CONN not-CONN became-QUE

'What is the reason $\mathrm{x}$ such that John didn't go to America?

*What is not the reason $\mathrm{x}$ such that John went to America for $\mathrm{x}$ ?

Since reason ettehkey is directly merged into $S p e c-\mathrm{C}_{\text {Int }} \mathrm{P}$, it is impossible for it to be interpreted under the negation.

The direct merge of reason ettehkey at Spec- $\mathrm{C}_{\text {Int }} \mathrm{P}$ straightforwardly explains why, just like way, it does not show the Intervention Effect when c-commanded by an SBE, as we have seen in (4): since reason ettehkey is licensed in its base-generated position, Spec- $\mathrm{C}_{\text {Int }} \mathrm{P}$, it does not undergo LF movement across the c-commanding SBE, thereby not violating the Intervention Effect constraint. The sentences involving reason ettehkey in (4) are assumed to have the LF structures presented in (17).
a. $\quad\left[\mathrm{CP} \mathrm{C}_{\mathrm{Foc}[+\mathrm{Q}]} \quad \ldots\right.$
amwuto $_{\mathbf{i}}$ ettehkey $\left.^{\mathrm{w}} \mathrm{C}_{\mathrm{Int}[+\mathrm{Q}]}\left[\mathrm{IP} \ldots \mathrm{t}_{\mathrm{i}} \ldots.\right]\right]$
(LF for (4a)) 


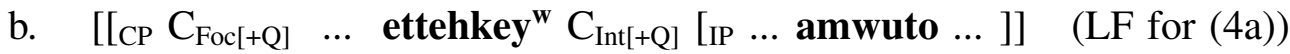

Meantime, if reason ettehkey is base-generated in $\mathrm{Spec}-\mathrm{C}_{\mathrm{Int}} \mathrm{P}$ of an embedded declarative clause and is preceded by a scrambled SBE, it exhibits the Intervention Effect just as way occurring in the same environment does (Ko 2005). Let us consider the following examples:
a. *John-un [amwuto $\left\{\right.$ ettehkey $\left.^{\mathbf{w}} / \mathbf{w a y}\right\} \mathrm{ku}$ chayk-ul ilk-ci anh-key John-TOP anyone how/why that book-ACC read-CONN not-CONN toyess-ta-ko] malhayss-ni?
became-DECL-COMP said-QUE
'What is the reason $\mathrm{x}$ such that John said that no one read that book for $\mathrm{x}$ ?'
b. John-un [amwuto $\left\{\right.$ ettehkey $\left.^{\mathbf{w}} / \mathbf{w a y}\right\} \mathrm{ku}$ chayk-ul ilk-ci anh-key John-TOP anyone how/why that book-ACC read-CONN not-CONN toyess-nunci] mwuless-ta. became-QUE asked-DECL 'John asked why no one read that book.' John-TOP Mimi-NOM how/why that book-ACC read-CONN toyess-ta-ko] malhayss-ni? became-DECL-COMP said-QUE 'What is the reason $\mathrm{x}$ such that John said that Mimi read that book for $\mathrm{x}$ ?'
c. John-un [Mimi-ka \{ettehkey $\left.{ }^{\mathbf{w}} / \mathbf{w a y}\right\} \mathrm{ku}$ chayk-ul ilk-key

The reason ettehkey in (18a) cannot be licensed in its base position because the embedded declarative $\mathrm{C}_{\text {Int }} \mathrm{P}$ lacks the [+Q] feature. Thus, for feature checking, it needs to move covertly to the matrix interrogative $\mathrm{C}_{\mathrm{Int}} \mathrm{P}$ containing [+Q]. However, the LF movement required is blocked by the scrambled subject SBE amwuto, inducing the Intervention Effect. This is illustrated in (19).

$$
\left[\begin{array}{llllllllll}
\mathrm{CP} 1 & \mathrm{C}_{\mathrm{Int}[+\mathrm{Q}]} & \ldots & {[\mathrm{CP} 2} & \text { amwuto }_{\mathbf{i}} & \text { ettehkey }^{\mathbf{w}} & \mathrm{C}_{\text {Int[-Q] }}\left[\begin{array}{llllll}
\mathrm{IP} & \ldots & \mathrm{t}_{\mathrm{i}} & \ldots
\end{array}\right]
\end{array}\right]
$$

Meantime, (18b) is grammatical since the reason ettehkey is licensed in its base position, i.e., the embedded interrogative $\mathrm{Spec}-\mathrm{C}_{\mathrm{Int}} \mathrm{P}$, and thus does not move across the c-commanding SBE:

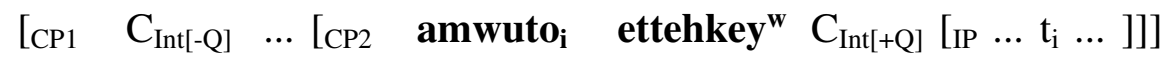

The well-formedness of (18c) is because no element blocks LF movement of the reason ettehkey to the matrix $\mathrm{C}_{\text {Int }} \mathrm{P}$ that does contain $[+\mathrm{Q}]$, as illustrated in (21).

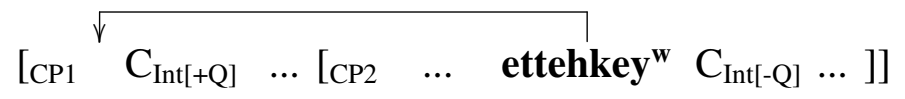

The same line of reasoning applies to the data involving way in (18) (see Ko 2005).

The analysis proposed here also provides an explanation for the Anti-Superiority Effect induced by reason ettehkey. Under the additional assumption that, like way, reason ettehkey functions as an SBE, the sentence in (6a) is ruled out because the SBE ettehkey interferes with LF movement of the $w h$-argument mwues-ul that it c-commands, inducing the Intervention Effect: ${ }^{7}$

\footnotetext{
${ }^{7}$ Like the regular reason wh-adjunct way, reason ettehkey gives rise to focus affected readings, as in (i), which supports its function as an SBE.
} 


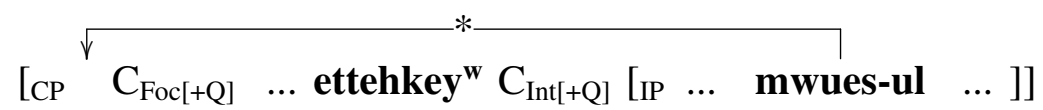

4.2. BASE-GENERATION OF MANNER/InSTRUMENTAL ettehkey BELOW NEGP. Example (23) illustrates the so-called how-why asymmetry with regard to the Negative Island Effect, a wellknown phenomenon in which negation blocks extraction of certain (wh-)phrases (Rizzi 1990; Tsai 2008; Shlonsky \& Soare 2011):

a. Why didn't Geraldine fix her bike?

b. *How didn't Geraldine fix her bike? (Shlonsky \& Soare 2011: (14))

The asymmetry can receive a natural account if we assume that unlike manner/instrumental how, reason why is directly merged in the CP domain (Rizzi 2001; Tsai 2008; a.o.). On this view, reason why is exempt from the Negative Island Effect since it originates above negation, i.e., NegP, as illustrated in (24a). Meantime, the ungrammaticality of (23b) can be explained by assuming that manner/instrumental how originates in a structurally lower position below negation; that is, the negator blocks LF movement of the wh-phrase to its scope position in the CP domain, as illustrated in (24b).
a. $\quad[$ СР why $[$ те $\ldots . . . \mathrm{NegP} \ldots .]$.

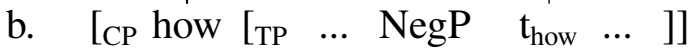

Note that such an asymmetry also holds for wh-questions in Korean:

a. Mimi-nun way cha-lul kochi-ci anh-ass-ni?

Mimi-TOP why car-ACC fix-CONN not-PST-QUE

'Why didn't Mimi fix the car?'

b. *Mimi-nun ettehkey cha-lul kochi-ci anh-ass-ni?

Mimi-TOP how car-ACC fix-CONN not-PST-QUE

'How didn't Mimi fix the car?'

As observed in (25a), the reason wh-adverb way is not subject to the Negative Island Effect,

(i) a. A: ettehkey ${ }^{\mathrm{w}}$ Adam-i sakwa-lul mek-key toyess-ni?

how Adam-NOM apple-ACC eat-CONN became-QUE

'Why did Adam eat the apple?'

B: hanunim-i kukes-ul uytohasiessu-nikka

God-NOM that-ACC intend-because

'because God intended it (to happen)'

b. A: ettehkey ${ }^{\mathrm{w}}$ ADAM-i sakwa-lul mek-key toyess-ni?

B: Ivu-ka Adam-eykey kwonhayssu-nikka

Eve-NOM Adam-DAT recommended-because

'because he was the one that Eve recommended (to eat the apple)'

c. A: ettehkey ${ }^{\mathrm{w}}$ Adam-i SAKWA-lul mek-key toyess-ni?

B: kukes-i cwupyeney iss-ten yulihan umsik iessu-nikka that-NOM around be-MOD only food be-because 'because it (the apple) was the only food around'

d. A: ettehkey ${ }^{w}$ Adam-i sakwa-lul MEK-key toyess-ni?

B: kukes-ulo mwues-ul halci mollassu-nikka that-with what-ACC to.do be.ignorant.of-because 'because he couldn't think of anything else to do with it' 
just like English why. This is readily explained by Ko's (2006) claim that way is externally merged in Spec- $\mathrm{C}_{\text {Int }} \mathrm{P}$ in the left periphery of the clause. On the other hand, the ill-formedness of (25b) can be accounted for by assuming that manner/instrumental ettehkey is base-generated below NegP and that its LF movement to Spec- $\mathrm{C}_{\mathrm{Foc}} \mathrm{P}$ is blocked by the negator, triggering the Negative Island Effect. Meanwhile, reason ettehkey is not subject to the Negative Island Effect, just like way, as in (26), which supports the claim that reason ettehkey is base-generated in the $\mathrm{CP}$ domain $\left(\right.$ Spec- $\left.\mathrm{C}_{\mathrm{Int}} \mathrm{P}\right)$.

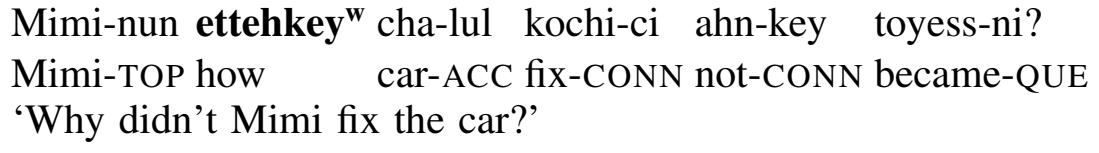

5. Conclusion. In this paper I have investigated reason ettehkey-questions and tried to answer the simple but important question of whether or not reason ettehkey originates in the same position as the regular wh-adjunct way 'why'. As for the question, I have proposed that reason ettehkey in an interrogative clause is externally merged in its checking position, $\mathrm{Spec}-\mathrm{C}_{\mathrm{Int}} \mathrm{P}$, just like way, whereas manner/instrumental ettehkey originates below NegP. If this syntactic analysis is correct, it lends support to previous research (e.g., Rizzi 2001; Ko 2006; Tsai 2008) arguing that a reason/causal $w h$-adverbial merges into the left periphery of the clause without undergoing (LF-)movement.

\section{References}

Beck, Sigrid. 2006. Intervention effects follow from focus interpretation. Natural Language Semantics 14. 1-56. https://doi.org/10.1007/s11050-005-4532-y.

Beck, Sigrid, \& Shin-Sook Kim. 1997. On wh-and operator scope in Korean. Journal of East Asian Linguistics 6(4). 339-384. https://doi.org/10.1023/A:1008280026102.

Bromberger, Sylvain. 1992. On what we know we don't know: Explanation, theory, linguistics, and how questions shape them. Chicago: University of Chicago Press.

Choi, Young-Sik. 2007. Intervention effect in Korean wh-questions: Indefinite and beyond. Lingua 117. 2055-2076. https://doi.org/10.1016/j.lingua.2007.01.001.

Ko, Heejeong. 2005. Syntax of why-in-situ: Merge into [Spec, CP] in the overt syntax. Natural Language \& Linguistic Theory 23(4). 867-916. https://doi.org/10.1007/s11049-004-5923-3.

Ko, Heejeong. 2006. On the structural height of reason $w h$-adverbials: Acquisition and consequences. In Lisa Cheng \& Norbert Corver (eds.), Wh-movement: Moving on. 319-349. Cambridge, MA: MIT Press.

Kotek, Hadas. 2014. Composing questions. Cambridge, MA: MIT dissertation.

Rizzi, Luigi. 1990. Relativized minimality. Cambridge, MA: MIT Press.

Rizzi, Luigi. 1999. On the position of "Int(errogative)" in the left periphery of the clause. Ms., Universit di Siena.

Rizzi, Luigi. 2001. On the position of "Int(errogative)" in the left periphery of the clause. In Guglielmo Cinque \& Giampaolo Salvi (eds.), Current studies in Italian syntax. 267-296. Amsterdam: Elsevier.

Saito, Mamoru. 1994. Additional-WH effects and the adjunction site theory. Journal of East Asian Linguistics 3(3). 195-240. https://doi.org/10.1007/BF01733064.

Shlonsky, Ur, \& Gabriela Soare. 2011. Where's 'why'? Linguistic Inquiry 42. 651-669. https://doi.org/10.1162/LING_a_00064. 
Tsai, Wei-Tien Dylan. 2008. Left periphery and how-why alternations. Journal of East Asian Linguistics 17. 83-115. https://doi.org/10.1007/s10831-008-9021-0.

Watanabe, Akira. 1992. Subjacency and S-structure movement of wh-in-situ. Journal of East Asian Linguistics 1(3). 255-291. https://doi.org/10.1007/BF00130554.

Yeo, Seungju. 2019. On the -key toy-construction as implicit causatives. Studies in Linguistics 51. 49-68. 